\title{
Fragmented Barley Grains from the Late Bronze Age Turnov-Maškovy Zahrady Site in North Bohemia
}

\author{
Alexandra Bernardováa, Veronika Komárkováa, Jan Prostředník ${ }^{\mathrm{b}}$, Jaromír Beneš ${ }^{\mathrm{a}^{*}}$ \\ ${ }^{a}$ Laboratory of Archaeobotany and Palaeoecology, Faculty of Science, University of South Bohemia, Branisovska 31,37005 České Budějovice, \\ Czech Republic \\ ${ }^{b}$ Museum of Bohemian Paradise, Skálova 71, 51101 Turnov, Czech Republic
}

\section{ARTICLE INFO}

Article history:

Received: 7 December 2010

Accepted: 14 February 2011

\section{Key words}

settlement site

Late Bronze Age

household

barley

bulgur

North Bohemia

\begin{abstract}
A B S T R A C T
Numerous fragments of predominately naked, six-row barley (Hordeum vulgare var. hexastichon) were found during archaeological research at the Late Bronze Age (c.1400-900 BC) site at TurnovMaškovy Zahrady in North Bohemia. There are no references to similar finds in the literature, making this find unique in Central Europe. Grains were found in three pits of various size and depth. The grains were fragmented prior to charring and did not have the shiny appearance associated with prior treatment with water. The spatial distribution of pits with fragmented charred grains is indicative of food preparation in the vicinity of houses. These finds resemble the fragmented cereal grains found in Bulgaria and northern Greece that mark the prehistoric origin of bulgur cereal preparation widely used in Mediterranean cuisine.
\end{abstract}

\section{Introduction}

The Turnov region is situated in the centre of the Český ráj (Czech Paradise) nature reserve, in the northern Czech Republic (Figure 1). The landscape is divided by the Jizera River, forming the main axis of a region that was geologically built up by sediments of the Upper Cretaceous. Today there are many small creeks and streams throughout this geomorphologically diverse area. The region was occupied in various prehistoric and medieval periods (Prostředník 1999). The Turnov-Maškovy Zahrady site is a well known archaeological settlement complex that has been under investigation since 1907. A large scale rescue excavation was undertaken between 1998 and 2001 in connection with development activity, with additional field work conducted in 2009. Important structures from the Late Bronze Age Lusatian Culture suggest intensive settlement activity between c. 1400 and 900 BC (Prostředník et al. 2010). Some settlement features were sampled for archaeobotanical

"Corresponding author. E-mail: benes.jaromir@gmail.com macro-remains. The article examines the unusual find of fragmented cereals: evidence of specific food preparation and the first record of this type of grain processing in the Central European Bronze Age.

\section{Material and methods}

\subsection{Archaeological context}

The Turnov-Maškovy Zahrady site lies in an almost alluvial soil, low on the left bank of the Jizera River, and almost within the floodplain. It is south west of the Turnov historic city centre (Figure 2). The site was an agricultural settlement, occupied from the Neolithic period (Linear Band and Stroked Pottery culture, 5500-4000 BC) to the end of the Early Medieval period (c. 1000-1250 AD). One key archaeological period recorded here is the Late Bronze Age. The known settlement structures from the period are some of the best preserved in the Czech Republic. Geological maps (1:50 000) identify the Turnov-Maškovy Zahrady site as located on a Quaternary loess or loess-like sediment, along the shallow bank terrace subject to occasional flooding from run off from 


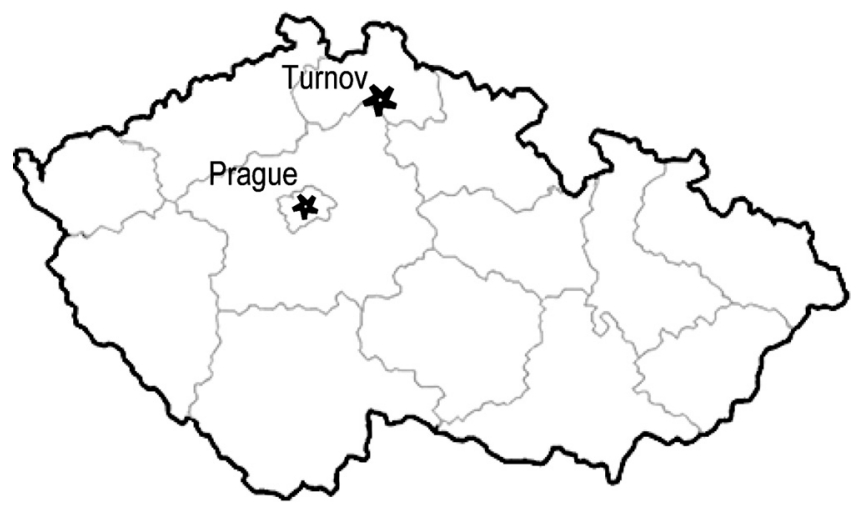

Figure 1. Site location in the Czech Republic. the Krkonoše Mountains to the north. The area of the rescue excavation extending over 8.3 ha and encompassed 650 sunken settlement features dated by relative chronology into a broad interval from the Middle Bronze Age ( $15^{\text {th }}$ century BC) until the Early Iron Age ( $5^{\text {th }}$ century BC).

A quite extraordinary component of the site is the taphonomical evidence of close to 15,000 traces of split tree trunks, which originally provided a hardened surface along the occupational horizon of the occasionally flooded Bronze Age settlement. Traces of wood working within the settlement area are well preserved thanks to subsequent alluvial deposits, which covered the Late Bronze Age settlement. Traces of surface alterations that have been found on the occupied horizon are interpreted as building platforms

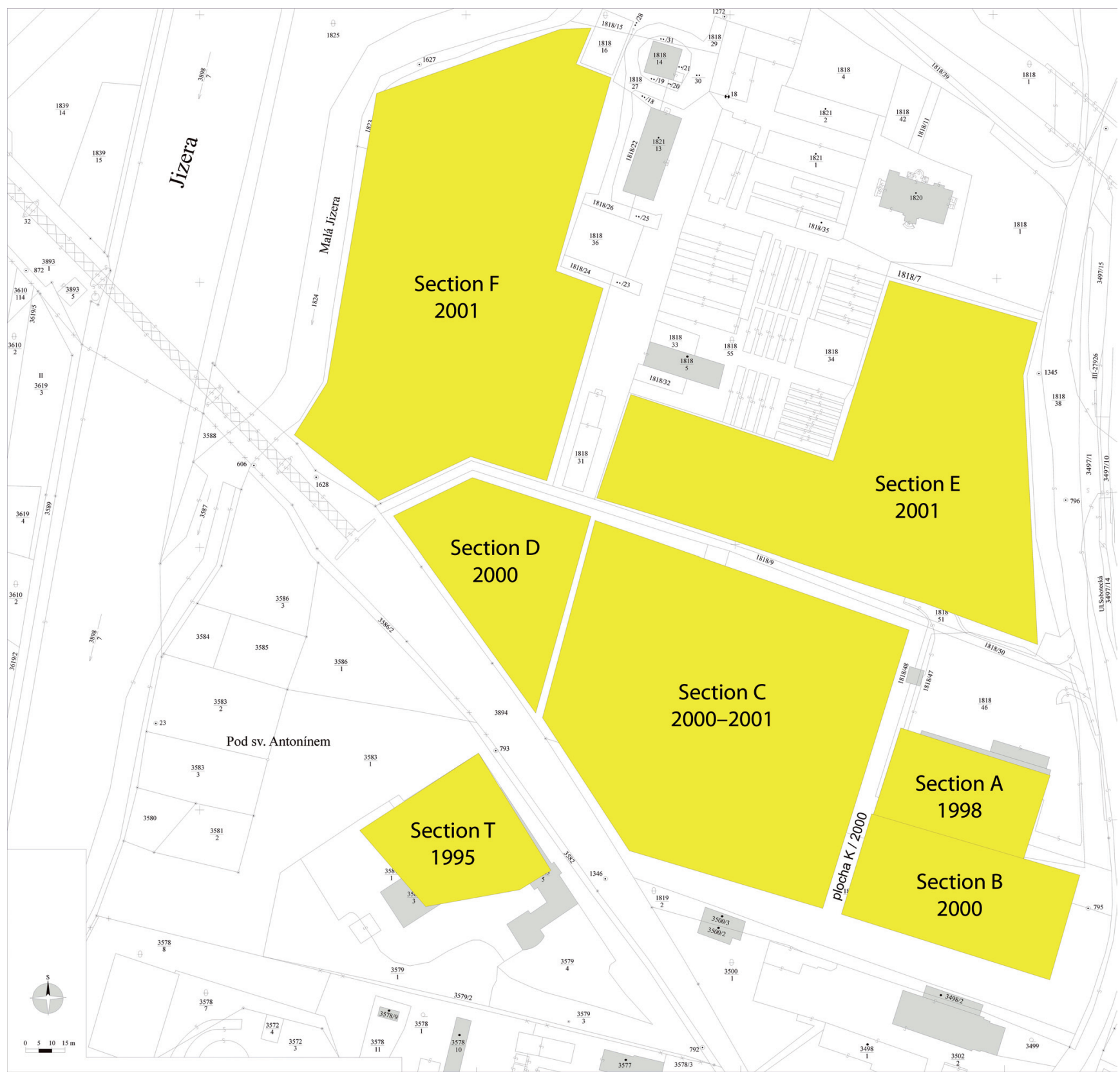

Figure 2. Turnov - Maškovy zahrady. Topographical situation of the site with indication of investigated sections (A-T) in 1998-2001. 


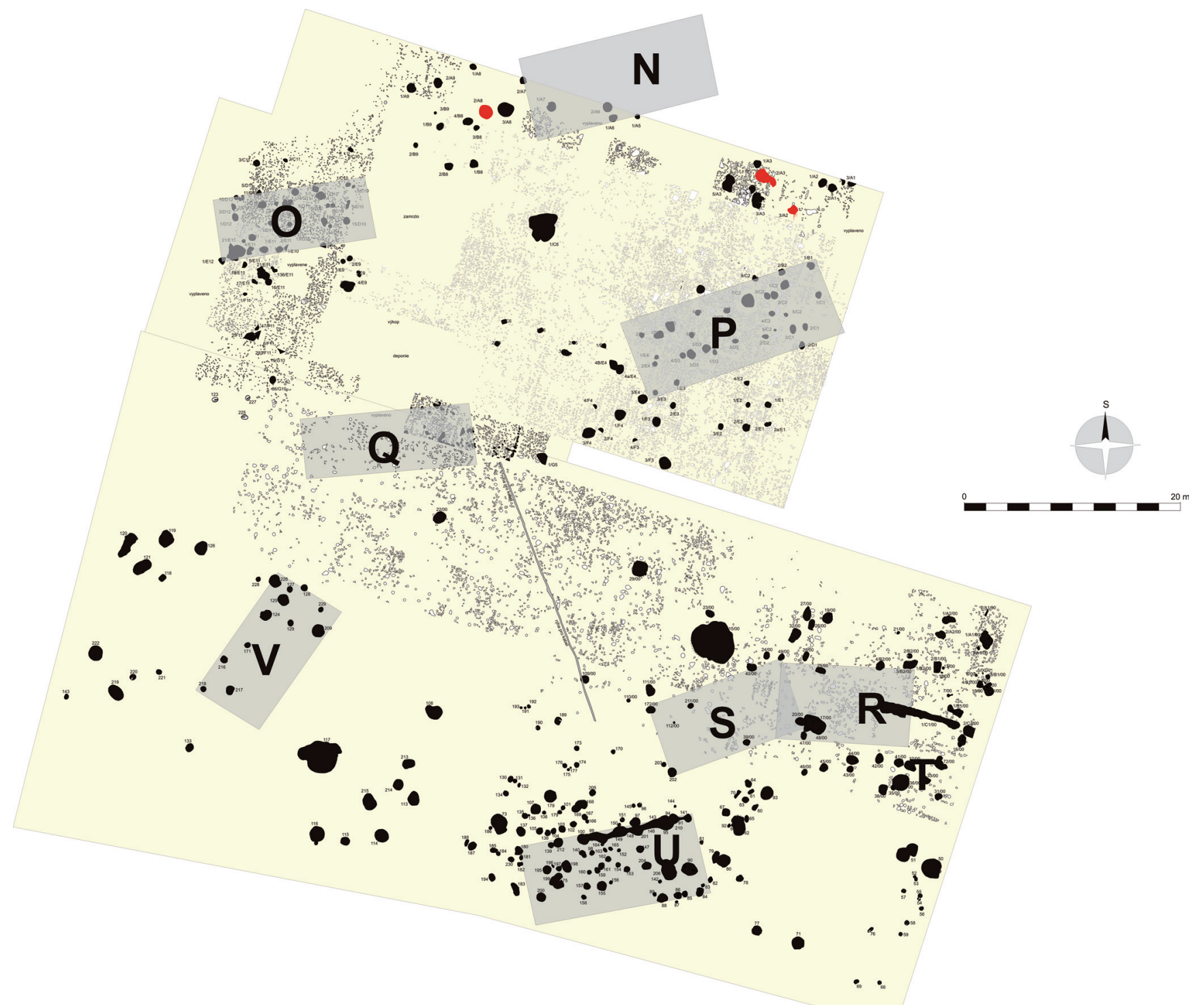

Figure 3. Turnov - Maškovy zahrady. General plan of the section A and B with indication of reconstructed position of the households N, O, P, Q, R, S, U and V. Red spots indicates sunken features with finds of fragmented barley.

for eight households in site area A and B, lying along an eastwest axis (Figure 3). This is the highest concentration of Late Bronze Age households in Turnov-Maškovy Zahrady, where a total of at least 15 households have been identified (BláhováSklenářová, Prostředník 2007; Prostředník et al. 2010). The houses were identified by postholes - which are very rare in the Czech Republic. The houses consist of 3 rows of large postholes (Říhovský 1982; Beneš 1987) along a west-east axis. Houses in Turnov-Maškovy Zahrady are constructed with two rooms of between 9.5 and $17 \mathrm{~m}$ in length, and 6 to $8 \mathrm{~m}$ in width. Archaeological structures from the Late Bronze Age were dated by relative ceramic chronology, combined with four absolute ${ }^{14} \mathrm{C}$ (carbon-14) dates, ranging from 1410 to $970 \mathrm{BC}$ (Table 1).

\subsection{Archaeobotanical sampling}

Samples for macro-remain analysis were taken from 33 larger sunken pits or features. 20 liters of sediments were

Table 1. Turnov - Maškovy zahrady. Radiocarbon dates from the context of the Late Bronze Age site.

\begin{tabular}{cccrccc}
\hline Cadaster & Site & Complex & Feature & Cal BC/AD & Probability 95\% & Relat. chron. \\
\hline Turnov & Maškovy zahrady & 1,395 & $547 / 00$ & $1,210-970$ & $92.70 \%$ & BD-HB \\
Turnov & Maškovy zahrady & 2,095 & $1,280 / 01$ & $1,320-1,110$ & $90.40 \%$ & BD-HB \\
Turnov & Maškovy zahrady & 2,282 & $1,805 / 01$ & $1,410-1,250$ & $92.60 \%$ & BC-BD \\
Turnov & Maškovy zahrady & 341 & $80 / 00$ & $1,310-1,050$ & $95.40 \%$ & BD-HB \\
\hline
\end{tabular}




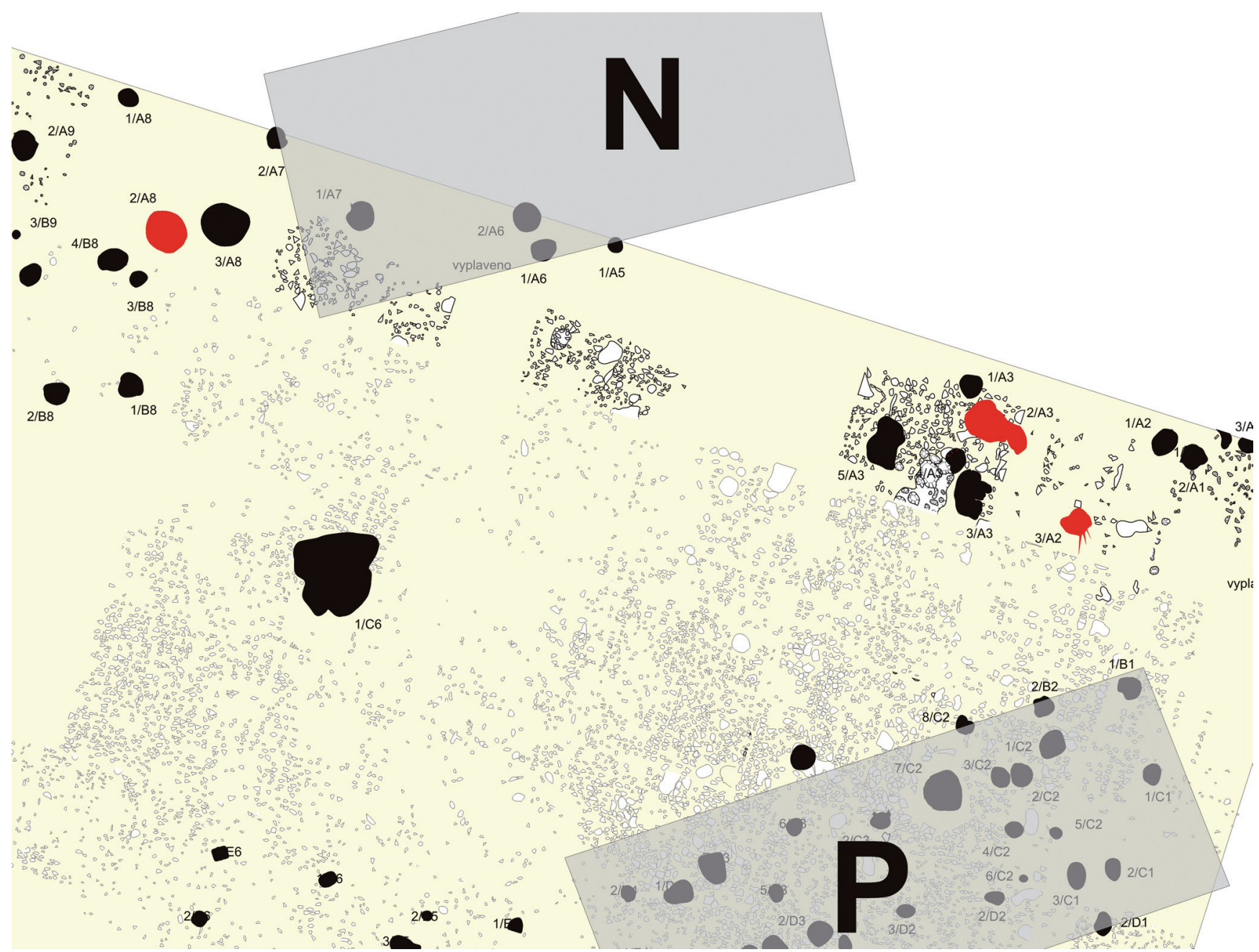

Figure 4. Detailed plan indicating position of sunken features (red color) with archaeobotanical finds in northern part of the section A.
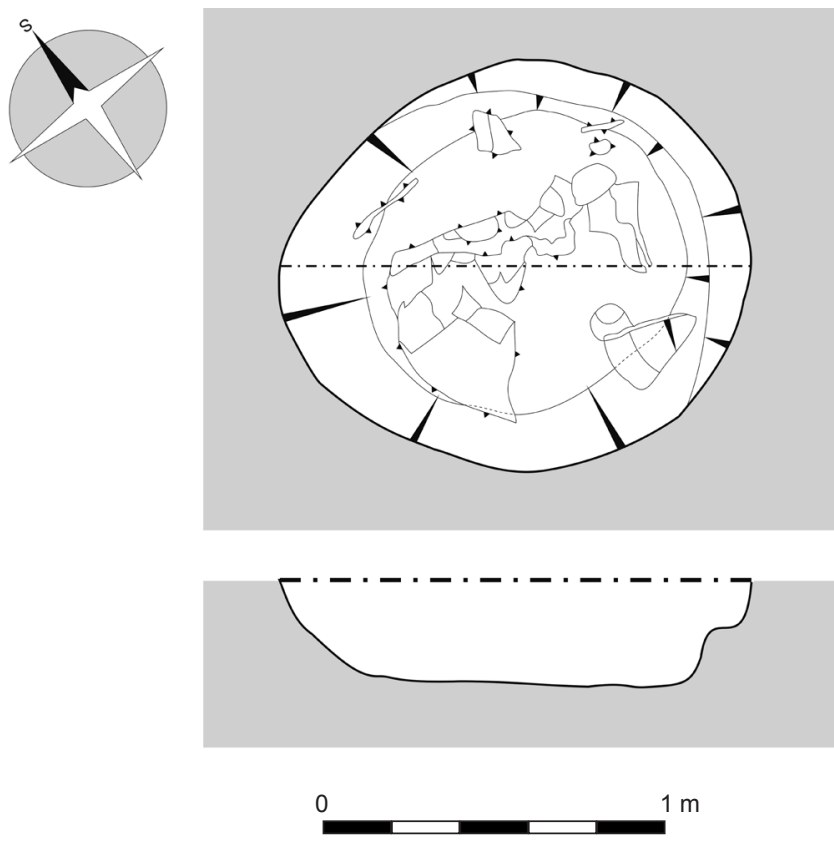

Figure 5. Pit 2/A 8 retrieved from each pit, processed by flotation with an Ankara machine (French 1971) with a $0.4 \mathrm{~mm}$ screen. Over 650 litres of sediment was processed. Laboratory identification was carried out with a stereomicroscope capable of 0.8 to $40 \mathrm{X}$ magnification.

\section{Results}

Charred archaeobotanical remains were found in only three sunken pit features in section $\mathrm{A}(2 / \mathrm{A} 8,2 / \mathrm{A} 3$ and $3 / \mathrm{A} 2)$. The pits were situated in the vicinity of houses (Figure 4 ). Feature $2 / \mathrm{A} 8$ is at the bottom of a round pit $140 \mathrm{~cm}$ in diameter and $40-50 \mathrm{~cm}$ deep. Infill was homogenous, with small stones at the bottom (Figure 5). Pit 2/A3 was an oval $210 \mathrm{~cm}$ along the axis and $20-60 \mathrm{~cm}$ deep. Infill formed two distinct layers (Figure 6). Pit 3/A2 was rounded, $80-90 \mathrm{~cm}$ in diameter and 10-20 cm deep. Infill was homogeneous (Figure 7). Pit 2/A8 was situated outside house $\mathrm{N}$ in prolongated axis, whereas pits 2/A3 and 3/A2 clustered between house $\mathrm{N}$ and $\mathrm{P}$. Other samples from the site were very poor and are not included in this evaluation. 

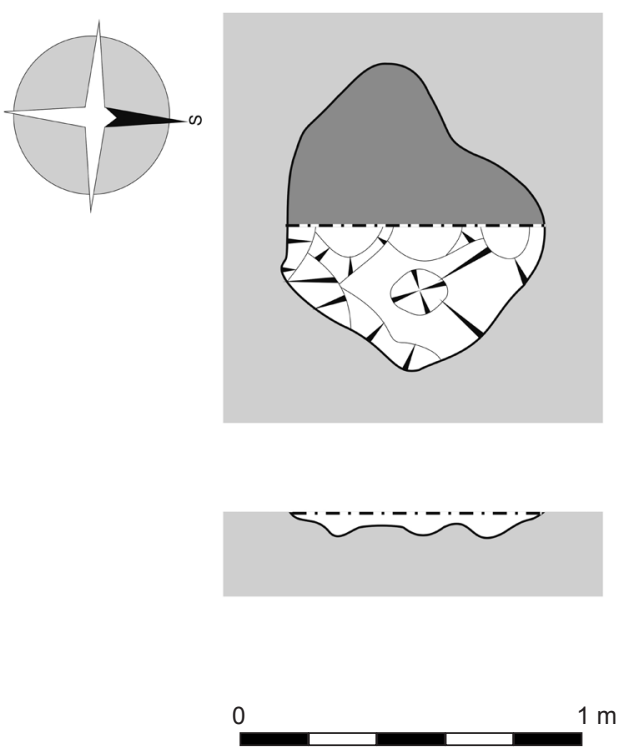

Figure 6. Pit 2/A3.
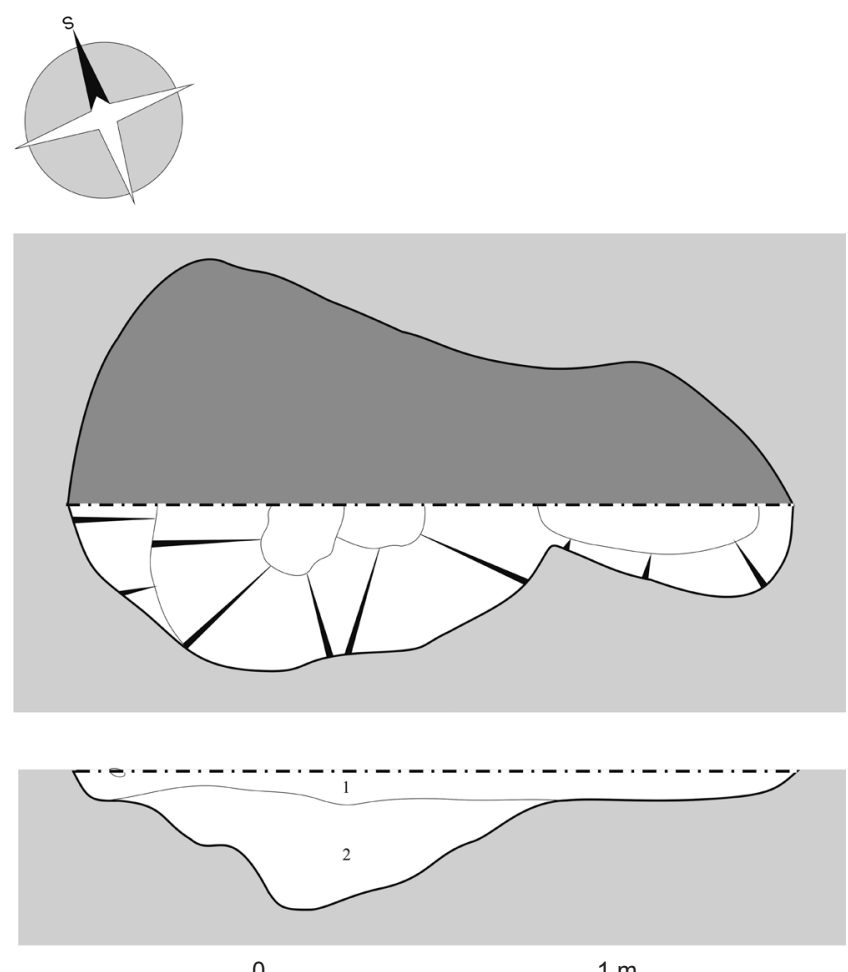

Figure 7. Pit 3/A2.

Table.2. Turnov - Maškovy zahrady. Table with macro-remains.

\begin{tabular}{|c|c|c|c|c|c|c|}
\hline \multicolumn{7}{|c|}{ Turnov - Maškovy zahrady } \\
\hline Chorred morofoscils & & 201 & 201 & 201 & & \\
\hline Chat Te matrossis & & 2/A3 & 2/A8 & 3/A2 & Sum & $\%$ \\
\hline \multirow{7}{*}{ Hordeum vulgare } & whole & 298 & 60 & 31 & 389 & 3.846914557 \\
\hline & apex & 172 & 17 & 17 & 206 & 2.037183544 \\
\hline & basis & 101 & 25 & 12 & 138 & 1.36471519 \\
\hline & centerpiece & 151 & 10 & 21 & 182 & 1.799841772 \\
\hline & fragments $2-4 \mathrm{~mm}$ & 1,234 & & 87 & 1,321 & 13.06368671 \\
\hline & fragments $<2 \mathrm{~mm}$ & 6,568 & 192 & 1,116 & 7,876 & 77.88765823 \\
\hline & & & & & 10,112 & \\
\hline Hordeum vulgare cf. var. hexastichon & sum & 2,182 & 282 & 117 & & \\
\hline Avenna sp. & & 1 & & & & \\
\hline Panicum millaceum & & 1 & 1 & 2 & & \\
\hline Secale cereale & & 1 & & & & \\
\hline Triticum aestivum & & 2 & & 1 & & \\
\hline Triticum mococcon/dicoccon & & 1 & 1 & & & \\
\hline Triticum dicoccon & & 6 & 2 & 1 & & \\
\hline Triticum sp. & & & $3 / 2$ & $2 / 2$ & & \\
\hline Cereralia & & $3+4 / 2$ & & & & \\
\hline Fallopia convolvulus & & & 1 & & & \\
\hline Galium cf. tricorne & & 3 & 1 & 2 & & \\
\hline Solanum dulcamara & & 1 & & & & \\
\hline Solanum cf. nigrum & & 1 & & & & \\
\hline Concentration per 11 & & 110 & 14.5 & 6 & & \\
\hline
\end{tabular}




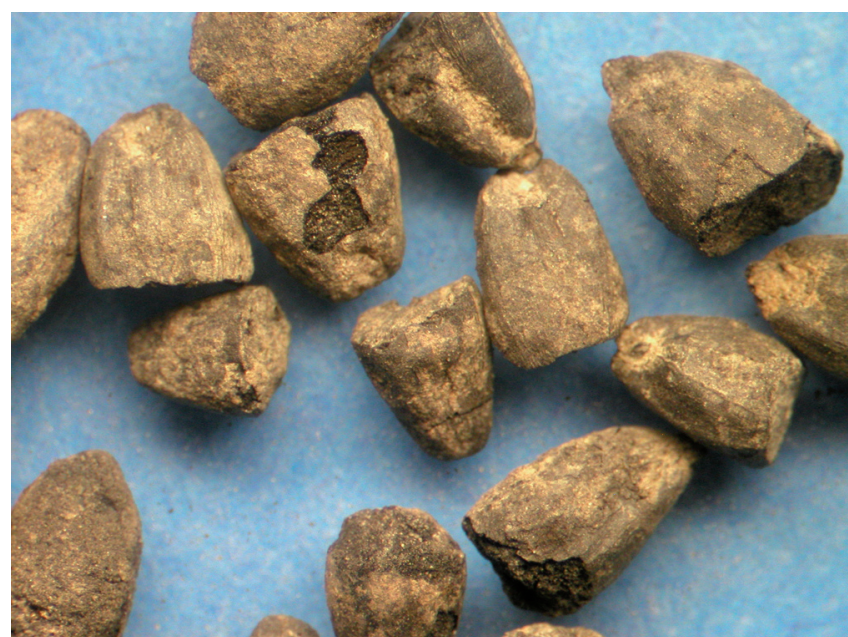

Figure 8. Apexes and basis of fragmented barley.

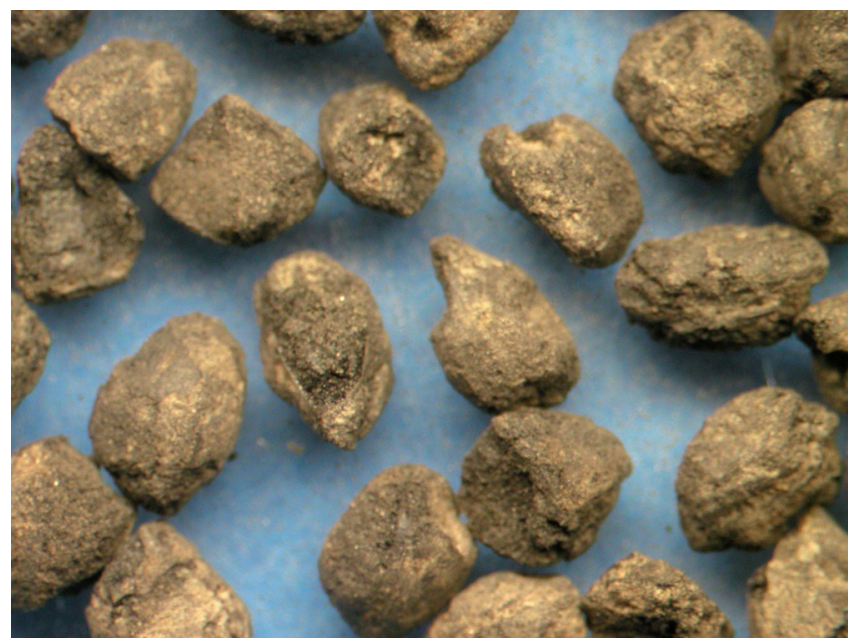

Figure 9. Fragments of barley (fraction 2-4 mm).

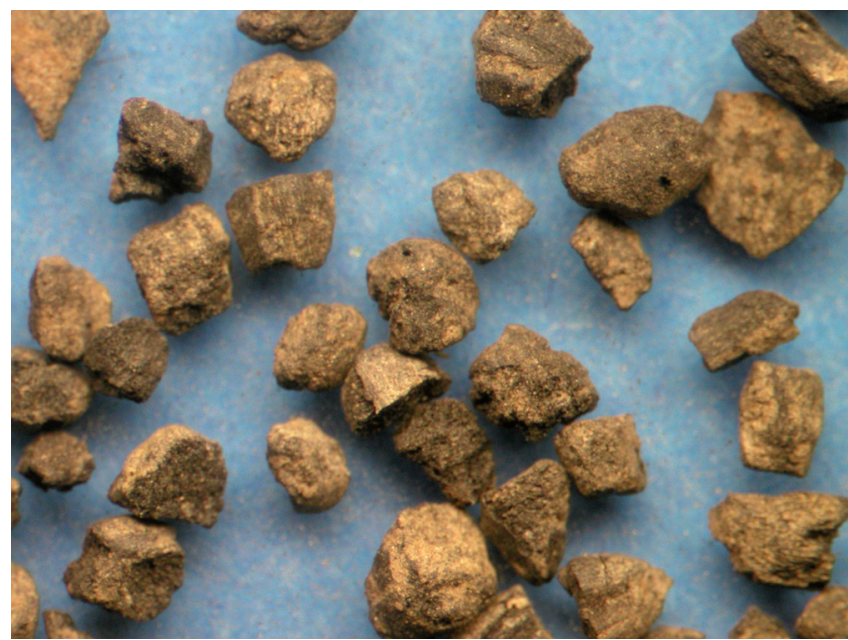

Figure 10. Fragments of barley (fraction under $2 \mathrm{~mm}$ ).
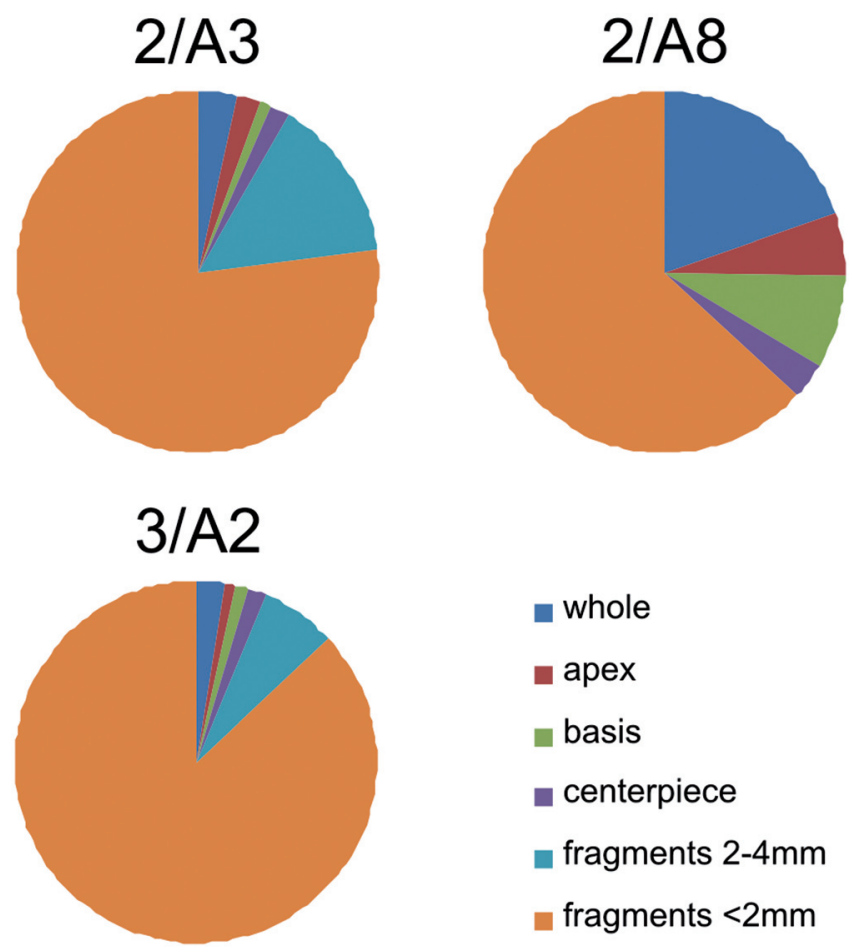

whole

apex

basis

centerpiece

- fragments $2-4 \mathrm{~mm}$

- fragments $<2 \mathrm{~mm}$

Figure 11. Taphonomical structure of fragmented barley in particular pits.

The finds from these three features (2/A3, 3/A2 and 2/A8) consisted of charred, fragmented cereal grains with a negligible quantity of crop weed species and ruderals. Altogether 10,112 charred objects were identified. The infill of pit 2/A 3 contained 110 finds per litre, while the infill of pit 3/A2 contained only six finds per litre. In all three features barley (Hordeum vulgare) (Table 2) was in absolute majority. One third of charred barley grains and fragments (mostly centrepieces) could be further identified as the $H$. vulgare var. hexastichon. Barley fragments from pits were suspiciously regular and can be divided into these categories:

a) whole grains $(3.8 \%)$,

b) apexes (2\%), basis $(1.4 \%)$, centrepieces $(1,8 \%)$,

c) larger fragments $2-4 \mathrm{~mm}(13,1 \%)$,

d) smaller fragments $<2 \mathrm{~mm}(77.9 \%$ ) (Figures 8, 9, 10).

It was not possible to determine species reliably for the majority of fragments of $<4 \mathrm{~mm}$. However, we thought it highly probable that the fragments were barley as well.

Tiny amounts of other cereals were found including; Triticum dicoccon (nine grains), Triticum aestivum (three grains), and Triticum monococcum (two grains) (see Table 2). Singular examples of the common crop weed or ruderal species Fallopia convolvulus, Galium sp., Solanum dulcamara, and Solanum cf. nigrum were also found.

There were more than 10,000 fragments of barley, which we attempted into a "whole grain" count. In the case of determinable remains, the highest number of either apexes or basis or centrepieces was taken as the number of grains.

Indeterminate remains were counted in the following manner: 
a) 100 whole grains were weighed on a scale and a mean single-grain weight calculated. Cereal fragments were weighted and the values converted into an equivalent "whole grains" number (based on the single-grain value).

b) Fragments of grains were spread on a graticule and the amount of fragments in one square was counted and multiplied with the number of squares.

Afterwards the fragments were recounted into a "whole grain". Fragments $2-4 \mathrm{~mm}$ were considered $1 / 2$ a whole grain and fragments $<2 \mathrm{~mm}$ as $1 / 6$ of a whole grain. Dividing the weight of 100 whole grains with the weight of 100 fragments provided a ratio of fragments to whole grains. Using this method we estimated that 2,500 whole grains are represented by the fragments found. All fragments from Turnov-Maškovy Zahrady are individual (not clumped). Almost $80 \%$ of fragments are smaller than $2 \mathrm{~mm}, 13 \%$ are 2-4 mm. The fracture surface is porous, rather smooth and without the shiny appearance that reflects previous treatment with water.

Charred fragments were located in three sunken features 2/A3, 3/A2 and 2/A8, which are spatially connected with houses $\mathrm{N}$ and $\mathrm{P}$ (Figure 4). Substantial finds were concentrated in the area of two spatially distinct pits 2/A3 and 3/A2, situated between houses $\mathrm{N}$ and $\mathrm{P}$. This find spot indicates food or supply processing activity was taking place outside the main buildings. Irregular postholes in the vicinity of pits imply a shelter. The substantial difference in concentration of archaeobotanical finds per volume between the pits may reflect the use of feature 2/A3 as a focal spot of refuse or storage activity, while the relatively lower concentration of finds in pit 3/A2 resulted from peripheral position of the sunken feature during barley processing or refuse action. The third pit (2/A8) was situated near house $\mathrm{N}$, probably also in a sheltered area, and as pit 3/A2 contained a lower concentration of charred macro-remains (Tab. 2), however, their presence in the deposit indicates treatment with fragmented barley generally.

The structure of macro-remain assemblage from TurnovMaškovy Zahrady, by taphonomical categories (Figure 11), shows an interesting difference between the contents of pits $2 / \mathrm{A} 3$ and 3/A2, and that of the more distant pit 2/A8. In the former the barley evidences subtle grinding, while in the later there is a higher ratio of whole grains. The prevalence of small fragments of barley should indicate the use of specific mode of preparation - boiling the cereals in water and grinding them into small pieces. This specific mode of preparation is known as bulgur in the Mediterranean cuisine (Bayram 2000).

\section{Discussion}

We can assume that the grains from Turnov-Maškovy Zahrady were fragmented prior to charring, as they lack deep hollows at the edges and sharp fractures (Hajnalová, personal communication). According to Valamoti`s research, and charring experiments, the surface of the grains from Turnov-Maškovy Zahrady did not resemble either the ancient nor the experimental ones (Valamoti 2002). Porous surface at the edges could suggest lower temperatures $\left(200{ }^{\circ} \mathrm{C}\right)$ during charring. It is very probable that the grains were not treated with water. Fragments would have a shiny appearance. On the other hand, when treated with very high temperatures during charring, the shiny appearance would not be visible as well as deep microscope hollows (Valamoti 2002). However, porous structure at the edges of fractures did not imply that.

Bulgur is a cereal product, which is precooked, dried, slightly scoured, pounded or ground. It is an ancient food product. Making wheat into bulgur originated in Anatolia and the Mediterranean. Grinding cereals produces finer, more homogeneous particles. This mode of food preparation is common in early prehistoric communities around the world (Gremillion 2004). The reduction of particle size exposes more starch to enzymes during digestion (Wright1994). Grinding of the cereals was carried out with saddle quern stones, which have been found as fragments in the same contexts. Use of flat or saddle quern stones is quite common in the Late Bronze Age (Jiráň, ed. 2008, 177).

Direct analogies of fragmented grains from TurnovMaškovy Zahrady are known from Greece and from Bulgaria. Bulgur deposits were recorded and published for the first time from Bronze Age sites in Greece (Valamoti 2002) from the settlements of Archondiko and Mesimeriani Toumba. Marinova (2006) has found earlier deposit of bulgur in Kapitan-Dimitrievo (South/Central Bulgaria) dated to 5920 to $5730 \mathrm{BC}$. The archaeobotanical assemblage from Archondiko expresses more similarities to Turnov-Maškovy Zahrady, as fragments are of similar size, even though the finds are from the interior of a house destroyed by fire. The assemblage from our site originated from sunken deposits outside the houses and very probably is the result of random refuse disposal.

Regardless of how exceptional the find may be, it remains likely that it was used as a food. There is a question of whether it was stored deliberately, or if there is another explanation for its archaeological deposition. A second question is whether it was intended for humans consumption or as fodder for animals (see discussion in Valamoti 2002). The storage of dehusked barley is rather extraordinary, as the peeled grains are not durable, in wet conditions could germinate (Bouby et al. 2005) and fragmented barley is not durable. The assumption that fragmented barley from Turnov - Maškovy zahrady was consumed by humans is supported by the purity of the seed assemblage, which contains almost no weeds or admixtures. This specific processing of cereals (in our case barley) is extraordinary amongst the current archaeobotanical collections of Central Europe.

The question of why fragmented grains (bulgur or bulgur-like products) are not common in archaeobotanical assemblages might be solved by consideration of the preservation of charred grains generally. The process of charring resulted from local small-scale events, when a grain store was exposed to heat or caught fire. A cereal supply that 
is already processed is soon consumed and usually without remains. Finds such as Archondiko and Turnov-Maškovy Zahrady seem to be randomly preserved testimony to the daily usage of barley in the human diet.

\section{Acknowledgement}

The work was supported by grant of Faculty of Science, University of South Bohemia (MSM6007665801 \& GAJU $138 / 2010 /$ P). Authors are very grateful to Eva and Maria Hajnalová for help with cereal identification and for the first comments to these finds and to Soultana Valamoti and Petr Šída for valuable comments.

\section{References}

BAYRAM, M. 2000: Bulgur around the world. Cereal Food World 45, $80-82$.

BENEŠ, J. 1987: Das Knovízer Gehöft in Liptice. In: Die Urnenfelder kulturen Mitteleuropas (Symposium Liblice 1985), 231-235. Praha.

BLÁHOVÁ-SKLENÁŘOVÁ, Z., PROSTŘEDNÍK, J. 2007: Chronologie sídliště lužické kultury v Turnově "Maškových zahradách". In: Doba popelnicových polí a doba halštatská. Príspěvky z IX. konference, Bučovice 3.-6. 10. 2006, 53-66, Brno.

BOUBY, L., FAGES, G., TREFFORT, J. 2005: Food storage in two Late Bronze Age caves of Southern France: palaeoethnobotanical and social implications. Vegetation History and Archaeobotany 14/4, 313-328.
FRENCH, D. H. 1971: An experiment in water-sieving, Anatolian Studies 21:59-64.

GREMILLION, K. J. 2004: Seed Processing and the Origins of Food Production in Eastern North America, American Antiquity 69. 2, 215233.

JIRÁŇ, L. (ed.) 2008: Archaeologie pravěkých Čech 5. Praha, Archeologický ústav AV ČR.

MARINOVA, E. 2006: Vergleichende palaoethnobotanische Untersuchung zur Vegetationsgeschichte und zur Entwicklung der prahistorischen Landnutzung in Bulgarien. Dissertation. Deposited: Bot 401 Cramer, Berlin.

PROSTŘEDNÍK, J. 1999: Archeologické výzkumy Okresního muzea Českého ráje v letech 1997 a 1998, Z Českého ráje a Podkrkonoši 12, 162-194.

PROSTŘEDNÍK, J., ŠÍDA, P., NOVÁK, J., BERNARDOVÁ, A., KOMÁRKOVÁ, V., THÉR, R. 2010: Turnov-Maškovy zahrady. Př́běh prastaré osady na břehu Jizery. Turnov.

ŘíHOVSKÝ, J. 1982: Hospodářský a společenský život velatické osady v Lovčičkách - Das Wirtschafts- und Gesellschaftsleben der Velaticer Siedlung in Lovčičky, Památky archeologické 73.1, 5-56.

SOKOLOV, R. 1991: Eating like a Noble Savage. Natural History 100.6, 74-75.

VALAMOTI 2002: Food remains from Bronze Age Archondiko and Mesimeriani Toumba in Northern Greece? Vegetation History and Archaeobotany 11, 17-22.

VALAMOTI, S., SAMUEL, D., BAYRAM, M., MARINOVA, E. 2008: Prehistoric cereal foods from Greece and Bulgaria: investigation of starch microstructure in experimental and archaeological charred remains, Vegetation History and Archaeobotany 17, 265-276.

WRIGHT, K. I. 1994: Ground-Stone Tools and Hunter-Gatherer Subsistence in Southwest Asia: Implications for the Transition to Farming, American Antiquity 59.2, 238-263. 